\title{
SOME GRÜSS' TYPE INEQUALITIES FOR TRACE OF OPERATORS IN HILBERT SPACES
}

\author{
Silvestru Sever Dragomir
}

Abstract. Some inequalities of Grüss' type for trace of operators in Hilbert spaces, under suitable assumptions for the involved operators, are given.

Mathematics subject classification (2010): 47A63, 47A99.

Keywords and phrases: Trace class operators, Hilbert-Schmidt operators, trace, Grüss' type inequalities, trace inequalities for matrices.

\section{REFERENCES}

[1] G. A. Anastassiou, Grüss type inequalities for the Stieltjes integral, Nonlinear Funct. Anal. Appl. 12 (2007), no. 4, 583-593.

[2] G. A. Anastassiou, Chebyshev-Grüss type and comparison of integral means inequalities for the Stieltjes integral, Panamer. Math. J. 17 (2007), no. 3, 91-109.

[3] G. A. Anastassiou, Chebyshev-Grüss type inequalities via Euler type and Fink identities, Math. Comput. Modelling 45 (2007), no. 9-10, 1189-1200.

[4] T. Ando, Matrix Young inequalities, Oper. Theory Adv. Appl. 75 (1995), 33-38.

[5] R. Bellman, Some inequalities for positive definite matrices, in: E.F. Beckenbach (Ed.), General Inequalities 2, Proceedings of the 2nd International Conference on General Inequalities, Birkhäuser, Basel, 1980, pp. 89-90.

[6] E. V. Belmega, M. Jungers And S. Las Aulce, A generalization of a trace inequality for positive definite matrices, Aust. J. Math. Anal. Appl. 7 (2010), no. 2, Art. 26, 5 pp.

[7] N. G. DE BRUiJn, Problem 12, Wisk. Opgaven, 21 (1960), 12-14.

[8] P. CERONE, On some results involving the Čebyšev functional and its generalisations, J. Inequal. Pure Appl. Math. 4 (2003), no. 3, Article 55, 17 pp.

[9] P. Cerone, On Chebyshev functional bounds, Differential \& difference equations and applications, 267-277, Hindawi Publ. Corp., New York, 2006.

[10] P. Cerone, it On a Čebyšev-type functional and Grüss-like bounds, Math. Inequal. Appl. 9 (2006), no. $1,87-102$.

[11] P. CERone And S. S. DRAGomir, A refinement of the Grüss inequality and applications, Tamkang J. Math. 38 (2007), no. 1, 37-49.

[12] P. Cerone And S. S. Dragomir, New bounds for the Čebyšev functional, Appl. Math. Lett. 18 (2005), no. 6, 603-611.

[13] P. CERone And S. S. Dragomir, Chebychev functional bounds using Ostrowski seminorms, Southeast Asian Bull. Math. 28 (2004), no. 2, 219-228.

[14] D. Chang, A matrix trace inequality for products of Hermitian matrices, J. Math. Anal. Appl. 237 (1999) 721-725.

[15] L. Chen AND C. Wong, Inequalities for singular values and traces, Linear Algebra Appl. 171 (1992), 109-120.

[16] I. D. CoOp, On matrix trace inequalities and related topics for products of Hermitian matrix, J. Math. Anal. Appl. 188 (1994) 999-1001.

[17] S. S. Dragomir, Grüss inequality in inner product spaces, The Australian Math Soc. Gazette, 26(1999), no. 2, 66-70. 
[18] S. S. DRAGOMIR, A generalization of Grüss' inequality in inner product spaces and applications, J. Math. Anal. Appl., 237 (1999), 74-82.

[19] S. S. Dragomir, Some discrete inequalities of Grüss type and applications in guessing theory, Honam Math. J., 21 (1) (1999), 145-156.

[20] S. S. Dragomir, Some integral inequalities of Grüss type, Indian J. of Pure and Appl. Math., 31 (4) (2000), 397-415.

[21] S. S. Dragomir, Advances in Inequalities of the Schwarz, Grüss and Bessel Type in Inner Product Spaces, Nova Science Publishers Inc, New York, 2005, x+249 pp.

[22] S. S. Dragomir AND G. L. Booth, On a Grüss-Lupaş type inequality and its applications for the estimation of p-moments of guessing mappings, Mathematical Communications, 5 (2000), 117-126.

[23] S. S. DRAGOMIR, A Grüss type integral inequality for mappings of $r$-Hölder's type and applications for trapezoid formula, Tamkang J. of Math., 31 (1) (2000), 43-47.

[24] S. S. Dragomir And I. Fedotov, An inequality of Grüss' type for Riemann-Stieltjes integral and applications for special means, Tamkang J. of Math., 29 (4) (1998), 286-292.

[25] S. S. DRAGOMIR, Čebyšev's type inequalities for functions of selfadjoint operators in Hilbert spaces, Linear Multilinear Algebra 58 (2010), no. 7-8, 805-814. Preprint RGMIA Res. Rep. Coll., 11(2008), Supp. Art. 9. [Online http://rgmia.org/v11(E) .php]

[26] S. S. DRAGOMIR, Grüss' type inequalities for functions of selfadjoint operators in Hilbert spaces, Ital. J. Pure Appl. Math. No. 28 (2011), 207-224. Preprint RGMIA Res. Rep. Coll. 11 (2008), Supp. Art. 11. [Online http://rgmia.org/v11(E).php]

[27] S. S. DRAGOMIR, New inequalities of the Kantorovich type for bounded linear operators in Hilbert spaces. Linear Algebra Appl. 428 (2008), no. 11-12, 2750-2760.

[28] S. S. Dragomir, Some Čebyšev's type trace inequalities for functions of selfadjoint operators in Hilbert spaces, Preprint RGMIA Res. Rep. Coll. 17 (2014), Art. 111.

[29] A. M. FInK, A treatise on Grüss' inequality, Analytic and Geometric Inequalities, 93-113, Math. Appl. 478, Kluwer Academic Publ., 1999.

[30] S. Furuichi AND M. Lin, Refinements of the trace inequality of Belmega, Lasaulce and Debbah, Aust. J. Math. Anal. Appl. 7 (2010), no. 2, Art. 23, 4 pp.

[31] G. GRÜSS, Über das Maximum des absoluten Betrages von $\frac{1}{b-a} \int_{a}^{b} f(x) g(x) d x-\frac{1}{(b-a)^{2}} \int_{a}^{b} f(x) d x$ $\int_{a}^{b} g(x) d x$, Math. Z., 39 (1935), 215-226.

[32] T. Furuta, J. Mićić Hot, J. PeČarić And Y. Seo, Mond-Pečarić Method in Operator Inequalities, Inequalities for Bounded Selfadjoint Operators on a Hilbert Space, Element, Zagreb, 2005.

[33] H. D. LeE, On some matrix inequalities, Korean J. Math. 16 (2008), no. 4, pp. 565-571.

[34] L. Liu, A trace class operator inequality, J. Math. Anal. Appl. 328 (2007) 1484-1486.

[35] Z. LiU, Refinement of an inequality of Grüss type for Riemann-Stieltjes integral, Soochow J. Math., 30 (4) (2004), 483-489.

[36] S. MAnjeg Ani, Hölder and Young inequalities for the trace of operators, Positivity 11 (2007), 239250.

[37] A. Matković, J. PeČARIĆ AND I. PeRIĆ, A variant of Jensen's inequality of Mercer's type for operators with applications Linear Algebra Appl. 418 (2006), no. 2-3, 551-564.

[38] D. S. Mitrinović, J. E. PeČArić And A. M. Fink, Classical and New Inequalities in Analysis, Kluwer Academic Publishers, Dordrecht, 1993.

[39] H. Neudecker, A matrix trace inequality, J. Math. Anal. Appl. 166 (1992) 302-303.

[40] B. G. PACHPATtE, A note on Grüss type inequalities via Cauchy's mean value theorem, Math. Inequal. Appl. 11 (2008), no. 1, 75-80.

[41] J. PeČARIĆ, J. MićIĆ AND Y. SEO, Inequalities between operator means based on the Mond-Pečarić method, Houston J. Math. 30 (2004), no. 1, 191-207

[42] M. B. RusKAI, Inequalities for traces on von Neumann algebras, Commun. Math. Phys. 26 (1972), 280-289.

[43] K. Shebrawi And H. Albadawi, Operator norm inequalities of Minkowski type, J. Inequal. Pure Appl. Math. 9 (1) (2008), 1-10, article 26.

[44] K. Shebrawi And H. Albadawi, Trace inequalities for matrices, Bull. Aust. Math. Soc. 87 (2013), 139-148.

[45] B. Simon, Trace Ideals and Their Applications, Cambridge University Press, Cambridge, 1979.

[46] Z. UluköK AND R. TÜRKMEn, On some matrix trace inequalities, J. Inequal. Appl. 2010, Art. ID 201486, 8 pp. 
[47] X. Yang, A matrix trace inequality, J. Math. Anal. Appl. 250 (2000) 372-374.

[48] X. M. Yang, X. Q. Yang And K. L. Teo, A matrix trace inequality, J. Math. Anal. Appl. 263 (2001), 327-331.

[49] Y. YAng, A matrix trace inequality, J. Math. Anal. Appl. 133 (1988) 573-574.

[50] C.-J. ZhaO AND W.-S. Cheung, On multivariate Grüss inequalities, J. Inequal. Appl. 2008, Art. ID 249438, 8 pp. 